\title{
GROWTH AND YIELD OF CORN IRRIGATED WITH SALINE WATER
}

\author{
Flávio Favaro Blanco ${ }^{*}$; Marcos Vinícius Folegatti²; Hans Raj Gheyi³; Pedro Dantas \\ Fernandes $^{3}$ \\ ${ }^{1}$ Embrapa Meio Norte, Av. Duque de Caxias, 5650 - 64006-220, Teresina, PI - Brasil. \\ ${ }^{2}$ USP/ESALQ - Depto. de Engenharia Rural, C.P. 9 - 13418-900 - Piracicaba, SP - Brasil. \\ ${ }^{3}$ UFCG/CCT - Depto. de Engenharia Agrícola, C.P. 10087 - 58109-970 - Campina Grande, PB - Brasil. \\ *Corresponding author 〈flavio@cpamn.embrapa.br>
}

\begin{abstract}
Corn (Zea mays L.) is an important crop in Brazil and is cultivated in all regions, including the semi-arid area of Brazil, where the occurrence of irrigation water with high concentration of salts is common. Evaluating the growth and yield of the maize hybrid 'AG 6690' irrigated with water of different salinity levels was the objective of this experiment. Sowing was performed in pots with 12 seeds on May 23, 2003, and seedlings were thinned to two plants per pot. Irrigation was accomplished when the mean soil matric potential of each treatment was approximately $-30 \mathrm{kPa}$ using water with seven different electrical conductivities (EC), varying from 0.3 to $4.5 \mathrm{dS} \mathrm{m}^{-1}$, which were obtained by addition of $\mathrm{NaCl}$ and $\mathrm{CaCl}_{2}$ in the equivalent proportion of $1: 1$. The dry weights of all parts of the corn plants as well as their evapotranspiration and water use efficiency were reduced by salinity. Grain yield decreased by 21 and $20 \%$ for each unit increase of $\mathrm{EC}_{\mathrm{i}}$ and electrical conductivity of soil solution $\left(\mathrm{EC}_{\mathrm{s}}\right)$ above the respective threshold values of 1.7 and $4.3 \mathrm{dS} \mathrm{m}$, respectivelly. Plants were able to maintain the leaf area index unaltered under moderate saline conditions.
\end{abstract}

Key words: Zea mays L., tolerance to salinity, soil solution, leaf area, evapotranspiration

\section{CRESCIMENTO E PRODUÇÃO DO MILHO IRRIGADO COMÁGUASALINA}

\begin{abstract}
RESUMO: O milho (Zea mays L.) é uma importante cultura no Brasil, sendo cultivado em todas as regiões, incluindo a região do semi-árido, onde é comum a ocorrência de águas com alta concentração de sais. Avaliar o crescimento e a produção do milho, híbrido 'AG 6690', irrigado com águas de diferentes níveis de salinidade foi o objetivo deste trabalho. O plantio foi realizado em vasos com 12 sementes por vaso, em 23 de maio de 2003, e realizado o desbaste deixando-se apenas duas plantas por vaso. A irrigação foi realizada sempre que o potencial mátrico médio do solo de cada tratamento aproximava-se de $-30 \mathrm{kPa}$, utilizando-se águas com sete diferentes condutividades elétricas $\left(\mathrm{EC}_{\mathrm{i}}\right)$ variando entre 0,3 e $4,5 \mathrm{dS} \mathrm{m}^{-1}$, as quais foram alcançadas pela adição de $\mathrm{NaCl}$ e $\mathrm{CaCl}_{2}$ na proporção equivalente de 1:1. O peso seco de todas as partes da planta foi reduzido pela salinidade, assim como a evapotranspiração e a eficiência de uso de água. A produção reduziu por 21 e $20 \%$ para cada aumento unitário de $\mathrm{EC}_{\mathrm{i}} \mathrm{e} \mathrm{EC}_{\mathrm{s}}$ (condutividade elétrica da solução do solo) acima dos valores limiares de 1,7 e 4,3 $\mathrm{dS} \mathrm{m}^{-1}$, respectivamente. As plantas foram capazes de manter a área foliar constante sob condições de salinidade moderada.

Palavras-chave: Zea mays L., tolerância à salinidade, solução do solo, área foliar, evapotranspiração
\end{abstract}

\section{INTRODUCTION}

Corn is one of the most important crops in the Brazilian Northeast agriculture, where the irrigation is required throughout the year, mainly in semi-arid areas. The waters used for irrigation in these areas, especially well waters, are frequently saline and/or alkaline, with high concentration of $\mathrm{Cl}^{-}$and, to a lesser extent, $\mathrm{Na}^{+}$(Medeiros et al., 2003; Cruz et al., 2003).

The first effect of salts is reducing the ability of plants to absorb water (osmotic effect), which leads to slower growth; second, salts may enter the transpiration stream and injure leaf cells, further reducing growth (Munns, 2005). The high concentration of $\mathrm{Na}^{+}$ and $\mathrm{Cl}^{-}$in soil solution is generally the main cause of the saline stress (Hasegawa et al., 2000) and the consequent slower growth is an adaptive feature for plant survival because it allows plants to rely on multiple resources to combat stress.

The response of crops to salinity may be simulated through the piecewise regression model proposed by Maas \& Hoffman (1977): 
$\mathrm{Yr}= \begin{cases}1 & 0 \leq \mathrm{c} \leq \mathrm{c}_{\mathrm{t}} \\ 1-\mathrm{s}\left(\mathrm{c}-\mathrm{c}_{\mathrm{t}}\right) & \mathrm{c}_{\mathrm{t}}<\mathrm{c} \leq \mathrm{c}_{0} \\ 0 & \mathrm{c}>\mathrm{c}_{0}\end{cases}$

where $\mathrm{Yr}$ is the relative yield, $\mathrm{c}$ is the mean salinity (electrical conductivity) in the root zone during the cultivation period $\left(\mathrm{dS} \mathrm{m}^{-1}\right), \mathrm{c}_{\mathrm{t}}$ is the salinity threshold value $\left(\mathrm{dS} \mathrm{m}^{-1}\right), \mathrm{c}_{0}$ is the salinity beyond which the yield is zero $\left(\mathrm{dS} \mathrm{m}^{-1}\right)$ and $\mathrm{s}$ is the absolute value of the slope of the response function between $\mathrm{c}_{\mathrm{t}}$ and $\mathrm{c}_{0}$.

Studies related to salinity tolerance of corn in Brazil are scarce. The present study was carried out with the objective of evaluating the growth and yield of the corn hybrid 'AG 6690', irrigated with water of different salinities.

\section{MATERIAL AND METHODS}

The experiment was conducted in a greenhouse covered with polyethylene film and closed with antiaphid screen, located in Piracicaba, SP, Brazil (22 $2^{\circ} 3^{\prime}$ $\left.\mathrm{S}, 47^{\circ} 38^{\prime} \mathrm{W}\right)$. Solar radiation, temperature and relative humidity were measured with an automatic weather station (Campbell Sci., model CR10) located in the center of the greenhouse.

The corn hybrid 'AG 6690' (three-way cross hybrid) was sown in $60 \mathrm{~L}$ pots, with diameter of 0.35 $\mathrm{m}$ at the top and $0.60 \mathrm{~m}$ height, containing a sandy loamy Typic Hapludox collected from the $0-0.3 \mathrm{~m}$ layer. Perforations were made in the bottom of the pots and a gravel layer of $3 \mathrm{~cm}$, covered with a polypropylene sheet, were added to allow the drainage of the excess water. The pots were placed $0.5 \times 1.0 \mathrm{~m}$ apart, considering their centers. The planting of the corn was accomplished in the spacing of $0.15 \mathrm{~m}$ among plants, with four seeds in each sowing position. Thus, 12 seeds of corn were sown in each pot at $2 \mathrm{~cm}$ depth, on May 23, 2003 (Figure 1). Seedlings were thinned out 20 days after sowing (DAS) and only three seedlings were left. A second thinning was accomplished

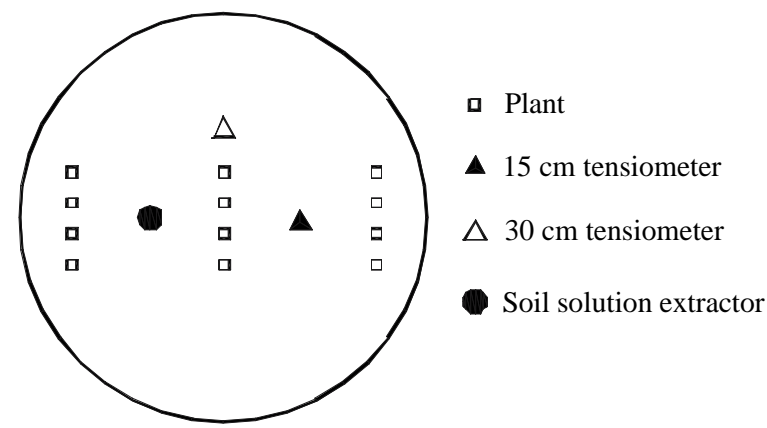

Figure 1 - Schematic representation of the planting positions of corn (with four seeds in each position) and location of the tensiometers and soil solution extractor. at 39 DAS and two seedlings were left giving an equivalent planting density of 40,000 plants ha ${ }^{-1}$.

Treatments were composed of seven levels of electrical conductivity of the irrigation water $\left(\mathrm{EC}_{\mathrm{i}}\right.$ of $0.3,1.0,1.7,2.4,3.1,3.8$ and $4.5 \mathrm{dS} \mathrm{m}^{-1}$ ), which were obtained by the addition of $\mathrm{NaCl}$ and $\mathrm{CaCl}_{2}$ in the equivalent proportion of $1: 1$ in tap water $\left(\mathrm{EC}_{\mathrm{i}}=\right.$ $0.3 \mathrm{dS} \mathrm{m}^{-1}$ ). A completely randomized block design with a single factor $\left(\mathrm{EC}_{\mathrm{i}}\right)$ was used with three replications, totaling 21 pots, each one composed of two plants.

Two tensiometers ( 0.15 and $0.30 \mathrm{~m}$ depth $)$ and one soil solution extractor $(0.15 \mathrm{~m}$ depth $)$ were installed in each pot for irrigation control and monitoring of $\mathrm{Ec}_{\mathrm{s}}$. Previously the soil had been cultivated with corn, in an experiment to evaluate the effects of salinity of the irrigation water on germination and initial development of the plants, and the salts were not leached after that because in the present study the germination and seedling growth were also determined to confirm the results of the earlier trial; thus the electrical conductivity of the soil solution $\left(\mathrm{EC}_{\mathrm{s}}\right)$ at planting was $0.9,1.7,3.5,3.9,4.3,5.6$ and $6.1 \mathrm{dS} \mathrm{m} \mathrm{m}^{-1}$, respectively, for the $\mathrm{EC}_{\mathrm{i}}$ of $0.3,1.0,1.7,2.4,3.1,3.8$ and $4.5 \mathrm{dS} \mathrm{m}^{-1}$.

All irrigations of each pot were accomplished with water of $\mathrm{EC}_{\mathrm{i}}$ corresponding to the respective treatment. The pots were irrigated with $5 \mathrm{~L}$ of water at planting, and received $20 \mathrm{~g}$ of monoamonium phosphate and $3.3 \mathrm{~g}$ of potassium chloride, which were applied with the irrigation water. At 40 and 80 DAS, $6.7 \mathrm{~g}$ of ammonium sulfate and $4.7 \mathrm{~g}$ of potassium chloride were applied per pot also through irrigation water.

Irrigations were accomplished whenever the mean soil matric potential approached $-30 \mathrm{kPa}$, the water being applied manually to each pot without wetting the leaves. The water depth was calculated based on the water retention curve of the soil (Blanco, 2004); the water depth applied was equivalent to allow a leaching fraction of 0.20 in all irrigation events, in order to maintain a better distribution of salts and to prevent excessive accumulation of the salts concentration in the soil profile. The irrigation frequency varied within the treatments due to the evapotranspiration reduction with increase of $\mathrm{EC}_{\mathrm{i}}$, with mean of 8.7 and 13.6 days for waters of 0.3 and $4.5 \mathrm{dS} \mathrm{m}^{-1}$, respectively.

Soil solution was collected at the beginning of the experimental period and at 31, 45 and 64 DAS, when the plants reached the flowering stage, and $\mathrm{EC}_{\mathrm{s}}$ was determined. Vacuum of about $-70 \mathrm{kPa}$ was applied after irrigation, when the soil matric potential was close to field capacity $(-6 \mathrm{kPa})$ and soil solution was removed from the extractor $24 \mathrm{~h}$ after vacuum was applied. 
Leaf area was estimated at 39 DAS; all leaves of all plants were measured and the leaf area was estimated by multiplying the product of length (L) and width (W) of respective leaf with a correction factor of 0.743 (Stewart \& Dwyer, 1999).

Evapotranspiration (ET) was estimated daily from the tensiometer readings and the soil water retention curve:

$\mathrm{ET}=\sum_{\mathrm{d}=7}^{125} \mathrm{ET}_{\mathrm{d}}$

$\mathrm{ET}_{\mathrm{d}}=\Delta S_{15}+\Delta S_{30} / \mathrm{N}_{\mathrm{d}}$

where $\mathrm{ET}_{\mathrm{d}}$ is the daily evapotranspiration of one plant on d DAS; $\Delta \mathrm{S}_{15}$ and $\Delta \mathrm{S}_{30}$ are the changes in water storage for the $0-15$ and $0-30 \mathrm{~cm}$ layers, respectively, on d DAS, and $\mathrm{N}$ is the number of plants in each pot on d DAS. For the days with irrigation, the $\Delta \mathrm{S}$ was calculated considering that the soil water content after watering was elevated to field capacity $(\theta=0.28$ $\mathrm{cm}^{3} \mathrm{~cm}^{-3}$ ).

Plant height was determined at 60 DAS by extending the leaves upwards and the maximum distance between soil surface and leaf tip was measured.

Harvest was performed at 150 DAS, when plants were completely dry. Plants were cut near the soil surface and grains, cob, straw and leaf + stem were dried at $60^{\circ} \mathrm{C}$ for $72 \mathrm{~h}$ and the dry weight was recorded. Grain yield was estimated by adjusting the grain moisture to $13 \%$ and the harvest index (HI) was calculated by dividing the dry weight of grains by the total dry weight of the plant. The water use efficiency (WUE) was calculated by the ratio between the grain yield and ET. The dry weight of seedlings pruned at 39 DAS was also determined and the absolute (AGR) and relative (RGR) growth rates were calculated as suggested by Benincasa (1988):

$\mathrm{AGR}=\left(\mathrm{D}_{2}-\mathrm{D}_{1} /\left(\mathrm{T}_{2}-\mathrm{T}_{1}\right)\right.$

and

$\mathrm{RGR}=\left[\ln \left(\mathrm{D}_{2}\right)-\ln \left(\mathrm{D}_{1}\right)\right] /\left(\mathrm{T}_{2}-\mathrm{T}_{1}\right)$

where $D_{1}$ and $D_{2}$ are the average dry weights $(g)$ for the first (39 DAS) and second (150 DAS) collections, respectively, and $T_{1}$ and $T_{2}$ are the sampling times for each growing period.

The analysis of variance was accomplished accordingly to Nogueira (1997) and, for variables with significant response to $\mathrm{EC}_{\mathrm{i}}$, the tolerance to salinity was determined using the software SALT (Genuchten, 1983), which makes the adjustment of the regression model by the piecewise linear regression method.

\section{RESULTS AND DISCUSSION}

The mean air temperature, relative humidity and solar radiation during the experimental period were $20^{\circ} \mathrm{C}, 69 \%$ and $6.8 \mathrm{MJ} \mathrm{m}^{-2} \mathrm{~d}^{-1}$, respectively. The accumulated growing degree-days was $1264^{\circ} \mathrm{C}$, and the observed meteorological conditions were favorable for corn development (Fancelli \& Dourado-Neto, 2000).

The electrical conductivity of the irrigation water $\left(\mathrm{EC}_{\mathrm{i}}\right)$ affected most variables related to the growth of corn plants (Table 1).

Using the $0.3 \mathrm{dS} \mathrm{m}^{-1}$ treatment as reference, the dry weight of stem and leaves (DWSL) was higher than the $100 \mathrm{~g}$ per plant found by Silva (2002) and are in agreement with Dourado-Neto (1999), who found DWSL values varying from 112 to $181 \mathrm{~g}$ per plant for different hybrids. The total dry weight (TDW)

Table 1 - Means and F-test for dry weight of straw and cob (DWSC), stem and leaves (DWSL), and total (TDW), plant height (PH), total (TLA) and mean (MLA) leaf area and absolute (AGR) and relative (RGR) growth rates of maize irrigated with saline water of different electrical conductivities $\left(\mathrm{EC}_{\mathrm{i}}\right)$.

\begin{tabular}{|c|c|c|c|c|c|c|c|c|}
\hline $\mathrm{EC}_{\mathrm{i}}$ & DWSC & DWSL & $\mathrm{TDW}^{\#}$ & $\mathrm{PH}$ & TLA & MLA & AGR & RGR \\
\hline $\mathrm{dS} \mathrm{m}^{-1}$ & $\ldots-\ldots$ & g per plan & 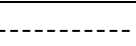 & $\mathrm{m}$ & $\mathrm{cm}^{2}$ per plant & $\mathrm{cm}^{2}$ per leaf & $\mathrm{g} \mathrm{d}^{-1}$ & $\mathrm{mg} \mathrm{mg}^{-1} \mathrm{~d}^{-1}$ \\
\hline 0.3 & 64 & 121 & 305 & 1.54 & 1992 & 317 & 2.92 & 32.0 \\
\hline 1.0 & 48 & 123 & 274 & 1.58 & 1774 & 249 & 2.91 & 33.6 \\
\hline 1.7 & 64 & 106 & 284 & 1.41 & 2241 & 280 & 2.71 & 31.1 \\
\hline 2.4 & 51 & 94 & 241 & 1.42 & 1706 & 230 & 2.13 & 32.1 \\
\hline 3.1 & 48 & 97 & 239 & 1.34 & 1086 & 170 & 2.20 & 38.2 \\
\hline 3.8 & 41 & 83 & 180 & 1.18 & 887 & 137 & 1.33 & 35.0 \\
\hline 4.5 & 34 & 64 & 149 & 1.00 & 1026 & 152 & 1.09 & 31.4 \\
\hline F-test ${ }^{\S}$ & $* *$ & $* *$ & $* *$ & $* *$ & $* *$ & $* *$ & $* *$ & ns \\
\hline SE & 12.3 & 10.3 & 27.0 & 0.1 & 424.8 & 50.6 & 0.3 & 4.3 \\
\hline
\end{tabular}

${ }^{\S} \mathrm{ns}, * *$ Non-significant and significant $(p<0.01)$, respectively. ${ }^{*}$ TDW $=$ DWSC + DWSL + DWG, where DWG is the dry weight of grains. 
was slightly lower than that of Dourado-Neto (1999), due to the high DWSC+DWG obtained in his experiment (above $200 \mathrm{~g}$ per plant for all hybrids), while in the present study the DWSC+DWG in the $0.3 \mathrm{dS} \mathrm{m}^{-1}$ treatment was of $184 \mathrm{~g}$ per plant. In general, the reduction of dry matter of different parts of maize was about $50 \%$ when $\mathrm{EC}_{\mathrm{i}}$ rose from 0.3 to $4.5 \mathrm{dS} \mathrm{m}^{-1}$.

Plant height $(\mathrm{PH})$ recorded for $0.3 \mathrm{dS} \mathrm{m}^{-1}$ was $1.54 \mathrm{~m}$, which was lower than $1.88 \mathrm{~m}$ recorded by Almeida et al. (2003). Total (TLA) and mean (MLA) leaf area of non-stressed plants were $1992 \mathrm{~cm}^{2}$ per plant and $317 \mathrm{~cm}^{2}$ per leaf, respectively. Manzatto (1987) found TLA varying from 1580 to $1802 \mathrm{~cm}^{2}$ per plant at $40 \mathrm{DAS}$, for four hybrids of corn, while André \& Ferraudo (1997) reported that the TLA of the cv. 'Maya-Normal' was $2844 \mathrm{~cm}^{2}$ per plant at 39 DAS. These differences of leaf area are expected because the leaf area depends on several variables like soil fertility, meteorological conditions, plant density and genetic characteristics of cultivars and hybrids (DouradoNeto, 1999).

The salinity of the irrigation water delayed the growth of the plants, with reduction of the absolute growth rate (AGR) of $63 \%$ at $\mathrm{EC}_{\mathrm{i}}$ of $4.5 \mathrm{dS} \mathrm{m}^{-1}$ in comparison to $\mathrm{EC}_{\mathrm{i}}$ of $0.3 \mathrm{dS} \mathrm{m} \mathrm{m}^{-1}$. On the other hand, the relative growth rate (RGR) was not affected by $\mathrm{EC}_{\mathrm{i}}$, which reveals that the growth relative to the amount of preexistent dry matter was the same for all levels of $\mathrm{EC}_{\mathrm{i}}$, that is, the growth potential of maize 'AG 6690' under low and high salinity was the same.

The $\mathrm{EC}_{\mathrm{i}}$ reduced grain yield, weight of 100 grains (W100) and evapotranspiration (ET) and had no effect on ear length (EL) and harvest index (HI) (Table 2).
The crop removes much of the water applied by irrigation from the soil to meet its evapotranspiration demand, but leaves most of the salts behind to concentrate in the soil solution (Ayers \& Westcott, 1999). The electrical conductivity of the soil solution $\left(\mathrm{EC}_{\mathrm{s}}\right.$ ) increased linearly with $\mathrm{EC}_{\mathrm{i}}$ and reached $7.5 \mathrm{dS}$ $\mathrm{m}^{-1}$ for the treatment irrigated with $\mathrm{EC}_{\mathrm{i}}$ of $4.5 \mathrm{dS} \mathrm{m}^{-1}$ (Figure 2). However, a change in the slope of the curve is clear after $\mathrm{EC}_{\mathrm{i}}$ of $1.7 \mathrm{dS} \mathrm{m} \mathrm{m}^{-1}$, probably due to the effect of the precipitation of salts of the soil solution with increasing concentration (Aragües et al., 1990). The presence of salts containing the common ion in the soil solution decreases the solubility of these salts (FAO, 1973), thus the application of a solution containing $\mathrm{CaCl}_{2}$ may lead to the precipitation of $\mathrm{Ca}$ salts, in the form of carbonate and sulphate minerals of low solubility, reducing the relative concentration of $\mathrm{Ca}$ in the soil solution.

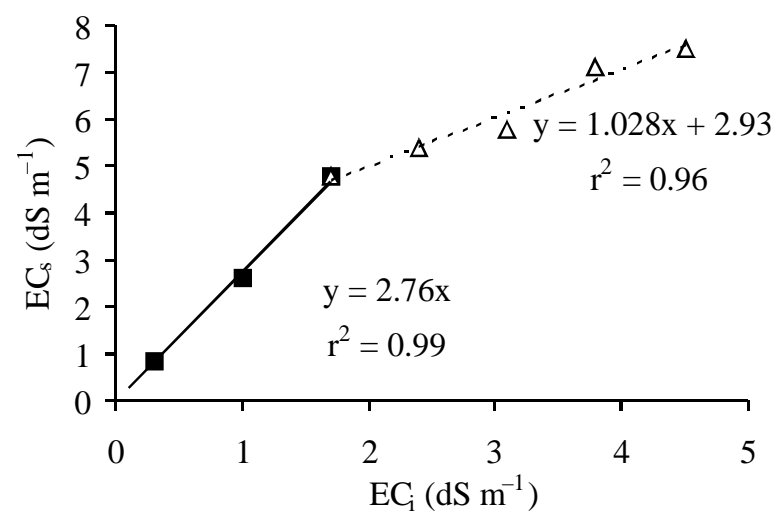

Figure 2 - Linear segment regression between mean electrical conductivity of soil solution $\left(\mathrm{EC}_{\mathrm{s}}\right)$ and electrical conductivity of the irrigation water $\left(\mathrm{EC}_{\mathrm{i}}\right)$.

Table 2 - Means and F-test for electrical conductivity of the soil solution $\left(\mathrm{EC}_{\mathrm{s}}\right)$, grain yield, weight of 100 grains (W100), ear length (EL), harvest index (HI), evapotranspiration (ET) and water use efficiency (WUE) of corn irrigated with saline waters of different electrical conductivities $\left(\mathrm{EC}_{\mathrm{i}}\right)$.

\begin{tabular}{|c|c|c|c|c|c|c|c|}
\hline $\mathrm{EC}_{\mathrm{i}}$ & $\mathrm{EC}_{\mathrm{s}}$ & Grain Yield & W100 & EL & $\mathrm{HI}$ & ET & WUE \\
\hline \multicolumn{2}{|c|}{ dS m ${ }^{-1} \ldots \ldots$} & $\mathrm{g}$ per plant & $\mathrm{g}$ & $\mathrm{cm}$ & & L per plant & $\mathrm{g} \mathrm{L}^{-1}$ \\
\hline 0.3 & 0.8 & 135 & 30.1 & 16 & 0.39 & 51.5 & 2.62 \\
\hline 1.0 & 2.6 & 131 & 26.6 & 16 & 0.37 & 57.2 & 2.29 \\
\hline 1.7 & 4.8 & 129 & 29.1 & 17 & 0.40 & 50.8 & 2.59 \\
\hline 2.4 & 5.4 & 109 & 25.8 & 16 & 0.40 & 53.4 & 2.05 \\
\hline 3.1 & 5.8 & 106 & 23.8 & 16 & 0.39 & 40.1 & 2.62 \\
\hline 3.8 & 7.1 & 63 & 19.8 & 16 & 0.31 & 35.8 & 1.73 \\
\hline 4.5 & 7.5 & 58 & 15.9 & 15 & 0.34 & 36.8 & 1.55 \\
\hline F-test ${ }^{\S}$ & $* *$ & $* *$ & $* *$ & ns & $\mathrm{ns}$ & $* *$ & $*$ \\
\hline SE & 0.7 & 20.0 & 3.3 & 2.0 & 0.04 & 5.1 & 0.4 \\
\hline
\end{tabular}

${ }^{\S} \mathrm{ns}, * *$, * Non-significant and significant at 0.01 and 0.05 level of probability, respectively. 
Electrical conductivity of the soil solution was 2.76 times higher than $\mathrm{EC}_{\mathrm{i}}$ up to $\mathrm{EC}_{\mathrm{i}}$ of $1.7 \mathrm{dS} \mathrm{m}^{-1}$, but above this limit the regression slope was practically equal to 1.0 for higher $\mathrm{EC}_{\mathrm{i}}$ with an intercept value of 2.93, which indicates that above the limit of $\mathrm{EC}_{\mathrm{i}}=$ $1.7 \mathrm{dS} \mathrm{m}^{-1}$ the electrical conductivity of soil solution increases by $2.93 \mathrm{dS} \mathrm{m}^{-1}$. This value is greater than the electrical conductivity of the saturated solution of calcium sulphate $\left(2.8 \mathrm{dS} \mathrm{m}^{-1}\right)$ (Hoorn \& Alphen, 1994); therefore, it is presumed that part of calcium precipitated as calcium sulphate is due to the application of ammonium sulphate.

Grain yield was reduced from 135 to $58 \mathrm{~g}$ per plant when $\mathrm{EC}_{\mathrm{i}}$ increased from 0.3 to $4.5 \mathrm{dS} \mathrm{m}^{-1}$. Water use efficiency (WUE) for grain production was 2.62 $\mathrm{kg} \mathrm{m}^{-3}$ and it decreased $41 \%$ for $\mathrm{EC}_{\mathrm{i}}$ of $4.5 \mathrm{dS} \mathrm{m}^{-1}$ (Table 2). Kang et al. (2000) found WUE of $2.61 \mathrm{~kg}$ $\mathrm{m}^{-3}$ for cv. 'Duanyu', and Howell et al. (1998) of about $1.55 \mathrm{~kg} \mathrm{~m}^{-3}$ for two hybrids of maize (Pioneer 3737 and Pioneer 3245). Reduction of WUE with increasing salinity was also observed by Guelloubi et al. (2005) and Shalhevet et al. (1986). On the other hand, Yazar et al. (2003) and Katerji et al. (1996) did not observe differences in WUE for corn irrigated with water of various levels of $\mathrm{EC}_{\mathrm{i}}$, with mean WUE of 1.13 and $1.12 \mathrm{~kg} \mathrm{~m}^{-3}$, respectively.

The mean harvest index (HI) was found to be 0.37 and was not affected by $\mathrm{EC}_{\mathrm{i}}$, which agrees with Yazar et al. (2003) and Pandey et al. (2000) (0.350.40 ), while Sá et al. (2002) found HI varying from 0.36 to 0.65 for various cultivars and hybrids, but in this case, the HI was calculated considering the total ear weight and not the kernel weight. In the present study, if the total dry matter of the ear is considered, then the HI would be in the range of 0.52 to 0.62 for treatments irrigated with water from 0.3 to $4.5 \mathrm{dS} \mathrm{m}^{-1}$, respectively.

Table 3 shows the parameters of the piecewise regression model adjusted by the SALT program. The most sensitive variable to salinity was DWSL, which was reduced for $\mathrm{EC}_{\mathrm{i}}$ down to $0.9 \mathrm{dS} \mathrm{m}{ }^{-1}$. This agrees with the statements of other authors that the vegetative development is more affected by salinity than the yield components (Maas et al., 1983; Willadino et al., 1994).

Maas et al. (1983) reported that grain yield of corn was not affected by $\mathrm{EC}_{\mathrm{i}}$ up to $4.6 \mathrm{dS} \mathrm{m}^{-1}$ for cultivars 'Bonanza' and 'Golden Cross Bantam', and Hoffman et al. (1983) showed that it was reduced by $14 \%$ for each ECs unit increase above $3.7 \mathrm{dS} \mathrm{m}^{-1}$ for cv. 'DeKalb XL75'. In the present work, yield of the hybrid 'AG 6690' tolerated $\mathrm{EC}_{\mathrm{i}}$ and $\mathrm{EC}_{\mathrm{s}}$ of 1.7 and 4.6 $\mathrm{dS} \mathrm{m^{-1 }}$ and reduced $21 \%$ and $20 \%$ for each unit increased in $\mathrm{EC}_{\mathrm{i}}$ and $\mathrm{EC}_{\mathrm{s}}$, respectively.

Maas \& Hoffman (1977) stated that a reduction of $50 \%$ in corn yield was observed for $\mathrm{EC}_{\mathrm{i}}$ of 3.9 $\mathrm{dS} \mathrm{m}{ }^{-1}$, which agrees with the results of the present study, where the same reduction was reached for $\mathrm{EC}_{\mathrm{i}}$ of $4.1 \mathrm{dS} \mathrm{m}^{-1}$ and the response curves were very similar (Figure 3).

The adjustment of the piecewise regression using the electrical conductivity of the soil solution $\left(\mathrm{EC}_{\mathrm{s}}\right)$ revealed that grain yield was not affected by $\mathrm{EC}_{\mathrm{s}}$ up to $4.6 \mathrm{dS} \mathrm{m}^{-1}$, but it decreased $20 \%$ for each unit increase of salinity above this threshold (Table 3 ). The total leaf area was the most tolerant variable to $\mathrm{EC}_{\mathrm{s}}$,

Table 3 - Values of threshold salinity $\left(c_{t}\right)$, slope $(s)$ and salinity for zero yield $\left(c_{0}\right)$ adjusted from the electrical conductivity of the irrigation water $\left(\mathrm{EC}_{\mathrm{i}}\right)$ and soil solution $\left(\mathrm{EC}_{\mathrm{s}}\right)$, for the relative values of the variables measured of corn.

\begin{tabular}{|c|c|c|c|c|c|c|}
\hline \multirow{2}{*}{ Variable $^{\#}$} & \multicolumn{3}{|c|}{$\mathrm{EC}_{\mathrm{i}}$} & \multicolumn{3}{|c|}{$\mathrm{EC}_{\mathrm{s}}$} \\
\hline & $\mathrm{c}_{\mathrm{t}}$ & $\mathrm{s}$ & $\mathrm{c}_{0}$ & $c_{t}$ & $\mathrm{~s}$ & $\mathrm{c}_{0}$ \\
\hline & $\mathrm{dS} \mathrm{m} \mathrm{m}^{-1}$ & & $\mathrm{dS} \mathrm{m}^{-1}$ & $\mathrm{dS} \mathrm{m}^{-1}$ & & $\mathrm{dS} \mathrm{m}^{-1}$ \\
\hline Grain yield & 1.7 & 0.21 & 6.4 & 4.6 & 0.20 & 9.6 \\
\hline W100 & 1.9 & 0.17 & 7.9 & 2.5 & 0.07 & 16.2 \\
\hline DWSC & 1.7 & 0.14 & 8.6 & - & - & - \\
\hline DWSL & 0.9 & 0.12 & 9.2 & 3.6 & 0.11 & 12.8 \\
\hline TDW & 1.6 & 0.16 & 7.7 & 4.6 & 0.16 & 10.8 \\
\hline $\mathrm{PH}$ & 1.2 & 0.10 & 11.5 & 4.2 & 0.10 & 14.7 \\
\hline TLA & 1.7 & 0.21 & 6.4 & 4.8 & 0.21 & 9.5 \\
\hline MLA & 1.3 & 0.18 & 7.0 & 1.2 & 0.08 & 13.3 \\
\hline ET & 1.4 & 0.12 & 9.7 & 4.3 & 0.11 & 13.1 \\
\hline WUE & 1.9 & 0.14 & 9.3 & 2.4 & 0.06 & 19.2 \\
\hline
\end{tabular}

${ }^{\#} \mathrm{~W} 100=$ weight of 100 grains; DWSC $=$ dry weight of straw and cob; DWSL = dry weight of stem and leaves; TDW = total dry weight; $\mathrm{TLA}=$ total leaf area; MLA = mean leaf area; $\mathrm{ET}=$ evapotranspiration; WUE $=$ water use efficiency. 
and the mean leaf area (MLA) was the least tolerant, but the reduction of TLA and MLA for unitary increase of $\mathrm{EC}_{\mathrm{s}}$ was $21 \%$ and $8 \%$, respectively. Thus, leaf expansion was inhibited even for low salinity levels and decreased slowly with the salinity increase. This decrease was compensated by a higher number of leaves produced at the moderate salinity levels, which increased the TLA (Figure 4).

To obtain more reliable results for crop yield in saline environments, different authors have established the relationship between relative yield (Y/Ymax) and relative evapotranspiration (ET/ETmax), as the relative evapotranspiration permits to evaluate to what extent crop water requirements have been satisfied, therefore it may serve as an indicator of the water supply conditions to crops (Katerji, 2002). In the present study, yield and evapotranspiration at $\mathrm{EC}_{\mathrm{i}}$ of $4.5 \mathrm{dS}$ $\mathrm{m}^{-1}$ were reduced by 57 and $29 \%$ in relation to $\mathrm{EC}_{\mathrm{i}}$ of

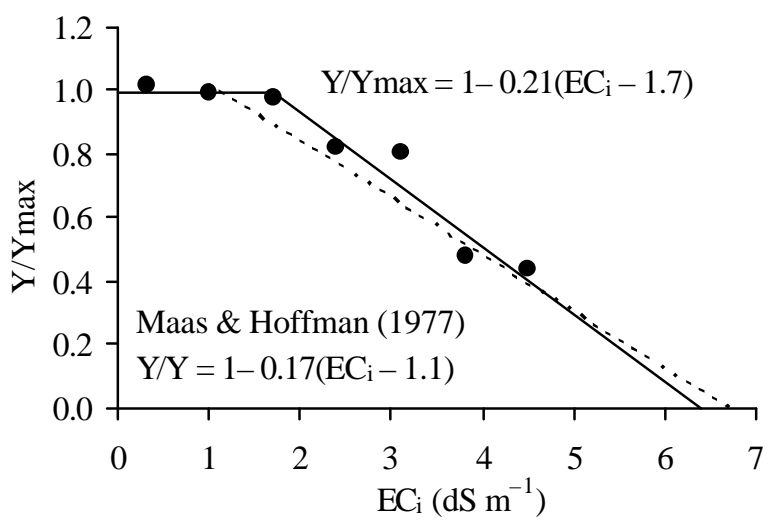

Figure 3 - Relative grain yield (Y/Ymax) of corn as a function of electrical conductivity of the irrigation water $\left(\mathrm{EC}_{\mathrm{i}}\right)$. Dashed line is the relative yield calculated using values of slope and threshold $\mathrm{EC}_{\mathrm{i}}$ presented by Maas \& Hoffman (1977).

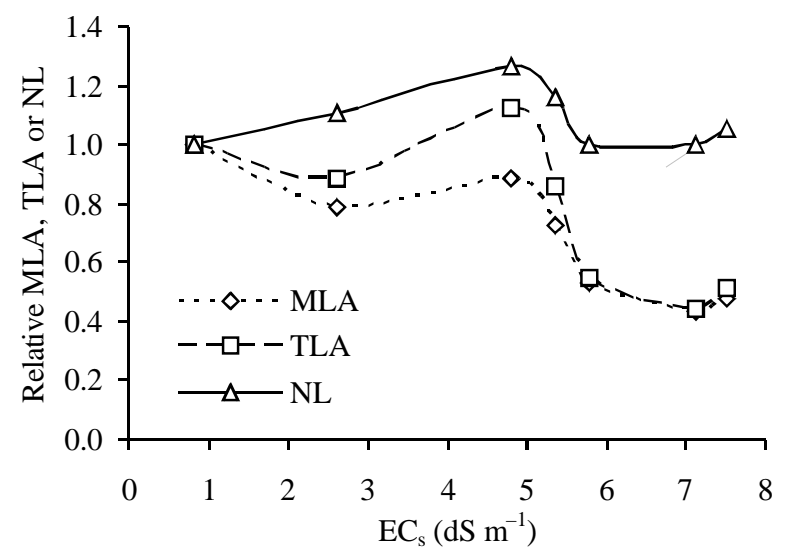

Figure 4 - Relative values of mean leaf area (MLA), total leaf area (TLA) and number of leaves (NL) of corn as a function of electrical conductivity of the soil solution $\left(\mathrm{EC}_{\mathrm{s}}\right)$.

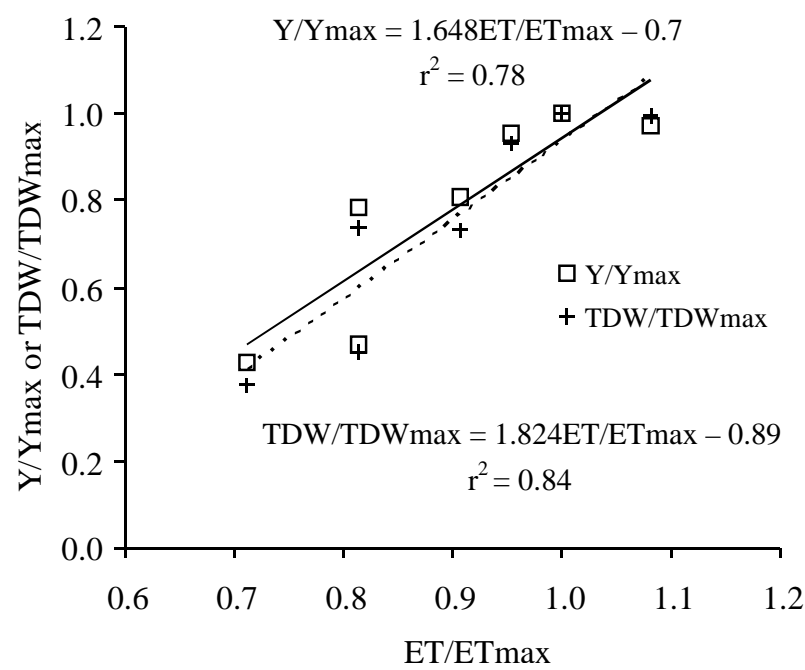

Figure 5 - Relation between relative yield (Y/Ymax) and total dry weight (TDW/TDWmax) with relative evapotranspiration (ET/ETmax) of corn.

$0.3 \mathrm{dS} \mathrm{m}^{-1}$, and the relationship between relative yield and relative ET was linear (Figure 5). This result is in agreement with Katerji et al. (2001), which found linear relationships between Y/Ymax and ET/ETmax for several crops under saline conditions, including corn.

\section{CONCLUSIONS}

The grain yield of the corn hybrid 'AG6690' is reduced by $20 \%$ for each unit increase in electrical conductivity of the irrigation water and of the soil solution above 1.7 and $4.6 \mathrm{dS} \mathrm{m}^{-1}$, respectively. The growth of corn is reduced with increase of salinity and the vegetative parts are more affected than the reproductive. Under saline stress the number of corn leaves increases in an attempt to maintain the total leaf area unaltered.

\section{REFERENCES}

ALMEIDA, M.L.; SANGOI, L.; NAVA, I.C.; GALIO, J.; TRENTIN, P.S.; RAMPAZZO, C. Crescimento inicial de milho e sua relação com o rendimento de grãos. Ciência Rural, v.33, p.189-194, 2003.

ANDRÉ, R.G.B.; FERRAUDO, A.S. Aspectos hídricos da cultura do milho (Zea mays L.). In: CONGRESSO BRASILEIRO DE AGrometeorologia, 10., Piracicaba, 1997. Anais. Piracicaba: Sociedade Brasileira de Agrometeorologia, 1997. p.629-631.

ARAGÜES, R.; TANJI, K.K.; QUILEZ, D.; FACI, J. Conceptual irrigation return flow hydrosalinity model. In: TANJI, K.K. (Ed.) Agricultural salinity assessment and management. New York: ASCE, 1990. cap.24, p.504-529.

ASHRAFUZZAMAN, M.; KHAN, M.A.H.; SHAHIDULLAH, S.M. Response of vegetative growth of maize (Zea mays) to a range of salinity. Online Journal of Biological Sciences, v.3, p.253-258, 2003.

AYERS, R.S.; WESTCOT, D.W. A qualidade da água na agricultura. 2.ed. Campina Grande: UFPB, 1999. 153p. (Estudos FAO: Irrigação e Drenagem, 29). 
BENINCASA, M.M.P. Análise de crescimento de plantas (noções básicas). Jaboticabal: FUNEP, 1988. 41p.

BLANCO, F.F. Tolerância do tomateiro à salinidade sob fertirrigação e calibração de medidores de íons específicos para determinação de nutrientes na solução do solo e na planta. Piracicaba: USP/ ESALQ, 2004. 115p. (Doutorado).

COUTO, L.; RESENDE, M.; ALBUQUERQUE, P.E.P. Importância do milho irrigado. In: RESENDE, M.; ALBUQUERQUE, P.E.P.; COUTO, L. (Ed.) A cultura do milho irrigado. Brasília: Embrapa Informação Tecnológica, 2003. cap.1, p.17-30.

CRAMER, G.R.; ALBERICO, G.J.; SCHMIDT, C. Leaf expansion limits dry matter accumulation of salt-stressed maize. Australian Journal of Plan Physiology, v.21, p.675-692, 1994.

CRUZ, M.G.M.; ANDRADE, E.M.; NESS, R.L.L.; MEIRELES, A.C.M. Caracterização das águas superficiais e subterrâneas do projeto Jaguaribe-Apodi. Engenharia Agrícola, v.23, p.187194, 2003.

DOURADO-NETO, D. Modelos fitotécnicos referentes à cultura de milho. Piracicaba: ESALQ/USP, 1999. 229p. (Livre Docência).

FANCELli, A.L.; DOURADO-NETO, D. Produção de milho. Guaíba: Agropecuária, 2000. 360p.

FOOD AND AGRICULTURE ORGANIZATION - FAO. FAOSTAT: agricultural data. Available at: http://faostat.fao.org. Accessed 4 Apr. 2006.

FOOD AND AGRICULTURE ORGANIZATION - FAO. Irrigation, drainage and salinity: an international source book. Paris: UNESCO/Hutchinson, 1973. 510p.

GENUCHTEN, M.T. van. Analyzing crop salt tolerance data: model description and user's manual. Riverside: USSL, 1983. 50p. (Research Report, 120).

GUELLOUBI, R.; HAMDY, A.; SARDO, V. Maize production under supplemental irrigation with saline water in rainfed agriculture. In: INTERNATIONAL CONFERENCE ON WATER, LAND AND FOOD SECURITY IN ARID AND SEMI-ARID REGIONS, 1., Valenzano, 2005. Proceedings. Valenzano: CIHEAM, 2005. CD-ROM.

HASEGAWA, P.M.; BRESSAN, R.A.; ZHU, J.K.; BOHNERT, H.J. Plant cellular and molecular responses to high salinity. Annual Review of Plant Biology, v.51, p.463-499, 2000.

HOFFMAN, G.J.; MAAS, E.V.; PRICHARD, T.L.; MEYER, J.L. Salt tolerance of corn in the Sacramento-San Joaquin Delta of California. Irrigation Science, v.4, p.31-44, 1983.

HOLANDA, J.S.; AMORIM, J.R.A. Qualidade da água para irrigação. In: GHEYI, H.R.; QUEIROZ, J.E.; MEDEIROS, J.F. (Ed.) Manejo e controle da salinidade na agricultura irrigada. Campina Grande: UFPB/SBEA, 1997. cap.5, p.137-169.

HOORN, J.W. van; ALPHEN, J.G. van. Salinity control. In: RITZEMA, H.P. (Ed.) Drainage principles and applications. 2.ed. Wageningen: International Institute for Land Reclamation and Improvement, 1994. cap.15, p.533-600.

HOWELL, T.A.; TOLK, J.A.; SCHNEIDER, A.D.; EVETT, S.R. Evapotranspiration, yield, and water use efficiency of corn hybrids differing in maturity. Agronomy Journal, v.90, p.3-9, 1998.

KANG, S.; SHI, W.; ZHANG, J. An improved water-use efficiency for maize grown under regulated deficit irrigation. Field Crops Research, v.67, p.207-214, 2000.

KATERJI, N. Productivity analysis of crops grown in saline environment: presentation of the major research lines. In: KATERJI, N.; HAMDY, A.; HOORN, I.W. van; MASTRORILLI, M. (Ed.). Mediterranean crop responses to water and soil salinity: eco-physiological and agronomic analyses. Bari: CIHEAM/IAMB, 2002. p.231-249. (Options Méditerranéennes: Serie B. Études et Recherches, 36).

KATERJI, N.; HOORN, J.W. van; HAMDY, A.; KARAM, F.; MASTRORILLI, M. Effect of salinity on water stress, growth, and yield of maize and sunflower. Agricultural Water Management, v.30, p.237-249, 1996.
KATERJI, N.; HOORN, J.W. van; HAMDY, A.; KARAM, F.; MASTRORILLI, M. Salt tolerance of crops according to three classification methods and examination of some hypothesis about salt tolerance. Agricultural Water Management, v.47, p. 1-8, 2001 .

LAZOF, D.B.; BERNSTEIN, N. The $\mathrm{NaCl}$ induced inhibition of shoot growth: the case for disturbed nutrition with special consideration of calcium. Advances in Botanical Research, v.29, p.113-189, 1999

MAAS, E.V.; HOFFMAN, G.J. Crop salt tolerance: current assessment. Journal of Irrigation and Drainage Division, v.103, p.115-134, 1977.

MAAS, E.V.; HOFFMAN, G.J.; CHABA, G.D.; POSS, J.A.; SHANNON, M.C. Salt sensitivity of corn at various growth stages. Irrigation Science, v.4, p.45-57, 1983.

MANZATTO, C.V. Acumulação de matéria seca e nutrientes em quatro híbridos de milho (Zea mays L.). Itaguaí:UFRRJ/IA, 1987. 157p. (Mestrado).

MEDEIROS, J.F.; LISBOA, R.A.; OLIVEIRA, M.; SILVA JÚNIOR, M.J.; ALVES, L.P. Caracterização das águas subterrâneas usadas para irrigação na área produtora de melão da Chapada do Apodi. Revista Brasileira de Engenharia Agrícola e Ambiental, v.7, p.469-472, 2003.

MUNNS, R. Genes and salt tolerance: bringing them together. New Phytologist, v.167, p.645-663, 2005.

NEUMANN, P.M.; VOLKENBURGH, E.V.; CLELAND, R.E. Salinity stress inhibits bean leaf expansion by reducing turgor, not wall extensibility. Plant Physiology, v.88, p.233-237, 1988.

NIEMAN, R.H. Expansion of bean leaves and its suppression by salinity. Plant Physiology, v.40, p.156-161, 1964.

NOGUEIRA, M.C.S. Estatística experimental aplicada à experimentação agronômica. Piracicaba: USP/ESALQ, 1997. $250 \mathrm{p}$.

PANDEY, R.K.; MARANVILLE, J.W.; CHETIMA, M.M. Deficit irrigation and nitrogen effects on maize in a Sahelian environment II. Shoot growth, nitrogen uptake and water extraction. Agricultural Water Management, v.46, p.15$27,2000$.

SÁ, M.; RAMALHO, M.A.P.; SOUZA SOBRINHO, F. Aspectos morfológicos e fisiológicos de cultivares modernas e antigas de milho. Ciência e Agrotecnologia, v.26, p.1082-1091, 2002.

SHALHEVET, J.; VINTEN, A.; MEIRI, A. Irrigation interval as a factor in sweet corn response to salinity. Agronomy Journal, v.78, p.539-545, 1986.

SILVA, C.J. Efeito de diferentes relações folhas/grãos sobre o metabolismo do nitrogênio em diferentes partes da planta de milho. Jaboticabal: UNESP/FCAV, 2002. 64p. (Mestrado).

STEWART, D.W.; DWYER, L.M. Mathematical characterization of leaf shape and area of maize hybrids. Crop Science, v.39, p.422-427, 1999.

WILlADINO, L.; CÂMARA, T.R.; TABOSA, J.N.; ANDRADE, A.G.; GOMES, R.V.; SOUZA, A.J. Avaliação de cultivares de milho em solo salino do semi-árido de Pernambuco. Pesquisa Agropecuária Brasileira, v.29, p.1059-1065, 1994.

YAZAR, A.; GENÇEL, B.; SEZEN, M.S. Corn yield response to saline irrigation water applied with a trickle system. Food, Agriculture \& Environment, v.1, p.198-202, 2003.

ZHU, J.K. Plant salt tolerance. Trends in Plant Science, v.6, p.66-71, 2001.

Received September 13, 2006

Accepted July 25, 2008 